\title{
Development Idiosyncratic Deals and Employee Performance
}

\author{
Mariam Tauba*1, Andrew Kimwolo (1D2 \\ 1,2 Moi University, Kenya \\ * Corresponding author: mariamtauba@gmail.com
}

\begin{abstract}
Article History
Received 2021-04-06

Revised 2021-05-02

Accepted 2021-05-06

Published 2021-05-07
\end{abstract}

\section{Keywords}

Development idiosyncratic deals

(Development I-deals)

Leader-Member-Exchange

Employee Performance

ICT organizations

\section{How to cite?}

Tauba, M., \& Kimwolo, A. (2021).

Development Idiosyncratic Deals and

Employee Performance. SEISENSE

Journal of Management, 4(3), 63-72. doi:

$10.33215 /$ sjom. 24 i3 .628
Employee performance has been at the helm of academic research over the years. The changing nature of work has unearthed several antecedents of job performance. The purpose of this study was to examine employee performance through the development of Idiosyncratic deals and Leader-Member-Exchange-quality lens of antecedents. The study is anchored on the social exchange theory. The hypotheses were tested on a sample of 325 employees of ICT firms in Uganda, using a cross-sectional survey. Three hundred two responses were used for analysis after cleaning of data. The direct hypotheses were tested using correlation analysis, while the mediation was tested using the Hayes Process macro model 4. The results supported the relationship between development idiosyncratic deals and employee performance and LMX quality and employee performance. This study found a significant mediating role of LMX-quality on the relationship between development idiosyncratic deals and employee performance. The study made contributions to the literature on idiosyncratic deals, employee performance, leader-member exchange quality as well, as the Social exchange theory. The study recommends adopting good quality LMX relationships to enhance the role of development idiosyncratic deals on employee performance among ICT firms. 


\section{Introduction}

Managing employees in recent times has come with increased pressure to perform from the employer. Many organizations continue to struggle to have and maintain a desirable level of employee performance, which remains a challenge. Statistics show that between 2006 and 2018, 67\% of organizations with more than 250 employees did not perform to set job standards (Volini et al., 2019). Organizations are thus left with few options to motivate employees to achieve a desirable level of performance (Leroy, Segers, Van Dierendonck, \& Den Hartog, 2018), for example, through negotiating employment terms. Attia, Duquenne, and Le-Lann (2014) advocate for increased flexibility in an organization by customizing workplaces. This has led to the popularity of idiosyncratic deals that provide the basis for negotiating work practices and customizing them to specific occupants of particular positions (Rousseau, 2015).

Idiosyncratic deals: These refer to voluntary and personalized agreements of a non-standard nature that individuals negotiate with their employers to benefit both parties (Rousseau, Tomprou, \& Simosi, 2016). While traditional models of employment terms, policies, and practices assume homogeneity in employment contracts among workers (Muchinsky, 2006), this is not how many contemporary organizations operate (Hornung, Rousseau, \& Glaser, 2008; Rousseau \& Kim, 2004). The negotiation of idiosyncratic deals has recently provided a new approach to managing human capital (Sun, Song, Kong, \& Bu, 2020). Idiosyncratic deals are negotiated on flexible work arrangements, the composition of tasks and responsibilities, workload reduction, and skills development (Rosen, Slater, Chang, \& Johnson, 2013). This study focuses on development idiosyncratic deals, which have been proven to promote skill development in a highly technical environment like the ICT sector.

These negotiations for Idiosyncratic deals usually happen between the employee and the employer or his agents, usually supervisors or leaders (Liao, Wayne, Liden, \& Meuser, 2017). A supervisor's value on their relationship with a particular employee positions them to demand privileges significantly greater than their less preferred coworkers. According to Hornung, Rousseau, Weigl, Mueller, and Glaser (2014), the quality of exchange relationships between leader and member (leader-member exchange) is positively related to the successful negotiation of various idiosyncratic deals. This study tests the mediating effect of leader-member exchange on the relationship between development idiosyncratic deals and employee performance.

\section{Literature Review}

\section{Theoretical Underpinning}

The study is premised on social exchange (Blau, 1964). The theory supports the numerous underlying approaches to studying relationships in organizations, especially employee-employer relationships (Shore, Coyle-Shapiro, Chen, \& Tetrick, 2009). The central principle of social exchange theory is that individuals tend to reciprocate contributions and favors with partners in a relationship, even when not otherwise required to do so (Blau, 1968). Applying social exchange theory in the context of development idiosyncratic deals would imply that employees with specialized career development opportunities feel obligated to reciprocate through positive work attitudes and behaviors that ultimately benefit the employer(Bos-Nehles \& Meijerink, 2018). Idiosyncratic deal recipients may reciprocate their favorable treatment by contributing in ways that benefit the employer who granted the deal. The reciprocity on the part of the employee as the I-deals recipient is evident in the I-deals theory (Anand, Hu, Vidyarthi, \& Liden, 2018), taking the form of discretionary contributions beneficial to the employer, such as organizational citizenship behavior (OCB). From the employer's perspective, Idiosyncratic deals may be a way to respond to an employee's contributions.

In this study, Social exchange theory provides a broad framework for explaining the relationship between development I-deals, LMX quality, and employee performance, building employee motivations who receive special treats from the employers at the workplace. 


\section{Hypothesis Development}

Development Idiosyncratic deals are characterized by customized negotiated arrangements that provide employees with career support and enriched skills (Hornung et al., 2014) opportunities to expand individual competencies and pursue career growth (Liao, Wayne, \& Rousseau, 2016). Developmental idiosyncratic deals represent unique resources to an employee that entails the physical, psychological, social, or organizational aspects (Bal \& Boehm, 2019). These include both on-the-job and off-the-job training opportunities. Career development opportunities to be negotiated include; customized coaching, mentoring, or study prospects granted to one employee but not the others. According to Srikanth, Jomon, and Thakur (2020), development idiosyncratic deals are the contemporary solution to provide employees with customized development resources, while benefiting the employer through better job outcomes.

Employee performance refers to the outcomes achieved and accomplishments achieved at work, including the efforts for keeping up plans while aiming for the results and comparing the targets and goals determined in advance (Sihombing, Astuti, Al Musadieq, Hamied, \& Rahardjo, 2018).

Leader-member exchange describes the variations of the relationships among the different employees and varies along a continuum from low to high quality (Graen \& Uhl-Bien, 1995). Leader-member exchange literature suggests that the relationships between managers and each of their employees are not equal. As a result, the support and resources available to the different differ, depending on the quality of the relationship (Martin, Guillaume, Thomas, Lee, \& Epitropaki, 2016).

\section{Development Idiosyncratic Deals and Employee Performance}

Through these I-deals, the employee and employer articulate and customize the employee's work activities, offering employees special opportunities to advance their knowledge and skills, consistent with increasing employee performance (Hornung, Rousseau, \& Glaser, 2009; Hornung et al., 2014). Accepting and granting employees unique career opportunities at their request will improve their motivation and zeal on the job. This stream of evidence suggests that both employees and managers view the granting of developmental opportunities as special and valuable, consistent with (Rousseau, Hornung, \& Kim, 2009). This is because the employees, upon taking on customized career development, offers to grow the skills that they apply directly to their jobs. Sun et al. (2020) confirm positive linkages between granting of development idiosyncratic deals and job outcomes. However, additional research has identified mixed results between idiosyncratic deals and varied job outcomes such as job satisfaction, innovative work behaviors, and OCB. Findings of the effect of customized development opportunities on employee performance remain scarce, yet it is the desirable direct output of a social exchange partnership. This study seeks to address that gap. We thus hypothesize that;

H1: Development idiosyncratic deals are related to employee performance

\section{Leader-Member Exchange and Employee Performance}

Leader-member exchange has steadily been linked to positive outcomes for employees, such as higher levels of job satisfaction, organizational commitment, innovative work behaviors, and citizenship behaviors (Epitropaki \& Martin, 2005; Martin, Thomas, Charles, Epitropaki, \& McNamara, 2005; Townsend, Phillips, \& Elkins, 2000). The social exchange theory propagates the case for negotiated exchanges between parties. It advances a leadership behavior that enhances a positive work climate for employees to execute their tasks and responsibilities. Carter, Armenakis, Feild, and Mossholder (2013) confirm that leadership behavior enhances the quality of relationships between employers and employees, which is necessary to improve employment output. This means that good quality exchange relationships between the leader and the subordinate are likely to yield positive job outcomes that stem from the loyalty and professional respect that constitute these kinds of relations instead of where the exchange relationships are of low quality. This study contributes a unique context 
of the ICT sector where advancements in technology warrant quality relationships for leaders to guide subordinates as they deal with unique challenges on the job. This study, therefore, hypothesizes that;

H2: Leader-Member exchange is positively related to employee performance

\section{The Mediating Role of Leader-Member Exchange Quality}

According to the LMX theory, leaders' positive behaviors can build an obligation for employees through forming a favor exchange(Li, Sanders, \& Frenkel, 2012). This favor exchange leads employees to be more trusting, competent on the job, and considerate. LMX and I-deals have been proven to be related, given that the negotiations usually happen with the employee's immediate manager or leader (Rosen et al., 2013). Even when the deal has been negotiated with another agent of the organization, such as a previous boss or an HR representative, immediate leaders are primarily responsible for ensuring smooth implementation of any subordinates' I-deals(Anand et al., 2018) by creating the environment in which it thrives and many times overseeing them.

Prior studies also explore the many potential positive outcomes of high-quality relationships between employees and leaders, including organizational commitment, satisfaction with the supervisor, job satisfaction, and promotion frequency. The quality of exchanges between a leader and their followers have an indirect effect on the customized negotiations and subsequent employee outcomes (Anand et al., 2018; Liao et al., 2017). Drawing from the social exchange theory, research has generally shown that employees perceiving a high level of exchange relationship with their leader may feel an obligation to work harder, resulting in favorable organizational consequences(Kim \& Koo, 2017). The research gap that remains unanswered is the influence of the exchange relationship between leader and subordinate on the granted idiosyncratic deals and employee outcomes. Srikanth et al. (2020) recommend testing organizational factors that can influence the impact of development idiosyncratic deals on employee job outcomes. This study responds to that call by testing the mediating effect of LMX quality on the relationship between development idiosyncratic deals and employee performance. It further adds a contextual contribution of the study on idiosyncratic deals on employee performance in the ICT sector in Uganda. This country faces high levels of unemployment and underemployment compared to the developed countries where most similar studies have been done before. The subsequent hypotheses, therefore;

H3: Idiosyncratic deals are related to Leader-Member exchange quality

H4: Leader-Member exchange quality mediates the relationship between development idiosyncratic deals and employee performance.

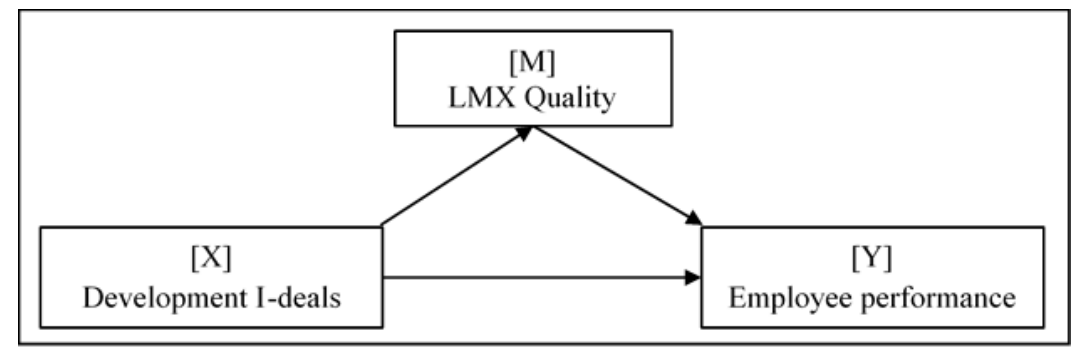

Figure 1 - Statistical diagram for the mediation analysis

\section{Methodology}

The study employed a cross-sectional survey design with 680 employees from six ICT institutions in Kampala. A sample of 325 employees was chosen using a simple random sampling technique. The sample comprised 
employees from middle and operational levels; these answered questions on development idiosyncratic deals and LMX quality while their immediate supervisors rated the questions on employee performance. This was done to prevent common source bias of employees providing self-rating on their performance. We used a closeended questionnaire to collect quantitative data on a drop-and-pick basis. The items were anchored on a fivepoint Likert-type scale. Three hundred two usable questionnaires were returned. The instrument was tested for validity using content validity where CVI of 0.8 and above for items were retained. We used the Chronbach alpha coefficients and only items with scores above the cutoff point of .70 were retained for reliability. The data were collected with the approval and consent of the individual institutions and respondents. The respondents were guaranteed confidentiality and anonymity.

The measurement of variables was based on literature. Development Idiosyncratic deals were measured using four items adapted from the scale by (Rosen et al., 2013) with sample items that include; "I have negotiated for an individual arrangement that allows me training opportunities," "I have negotiated a unique plan that allows me on-the-job training activities," "I can negotiate for arrangements that allow me special opportunities for career development," "My supervisor creates for me career development opportunities." Leader-MemberExchange Quality was measured using twelve items adopted from LMX Multidimensional scale by (Liden \& Maslyn, 1998); sample items include; "I am willing to apply extra efforts, beyond those normally required, to further the interests of my supervisor," "I admire my supervisor's professional skills." Employee performance was measured using sixteen items adopted from a scale by (Williams \& Anderson, 1991); sample items included; "This staff adequately completes assigned duties," "This staff fulfills responsibilities specified in his/her job description."

\section{Results}

The demographic characteristics results showed that most of the respondents were aged between 25-35years and these comprised $55.5 \%$ of the sample. The results from the age demographics reflect the composition of the workforce in the ICT sector to be of mid-age, consistent with the structure of the country's population. The results further indicated that the respondents in the age bracket 57-67 and those 68 comprised 10\% and $0.3 \%$ of the sample. This suggests that fewer employees in this age range could be due to the nature of jobs in the ICT sector that require versatility and pro-technology skills that most of these may not be as efficient in.

Additionally, $60.2 \%$ of the respondents were male, indicating the nature of the ICT to be perceived to be more masculine given the nature of technical activities involved. Also, $60 \%$ of respondents had spent 1-5 years, and only $6 \%$ had spent more than 10 years with their current employer.

\section{Correlation analysis}

Table 1: Pearson's correlations results

\begin{tabular}{llllllll}
\hline & 1 & 2 & 3 & 4 & 5 & 6 & 7 \\
\hline Gender (1) & 1.000 & & & & & & \\
Education Level (2) & 0.068 & 1.000 & & & & & \\
Age group (3) & 0.032 & $0.254^{* *}$ & 1.000 & & & & \\
Length of service (4) & -0.058 & $0.278^{* *}$ & $0.553^{* *}$ & 1.000 & & & \\
Employee Performance (5) & -0.011 & -0.067 & $0.163^{* *}$ & $0.127^{* *}$ & 1.000 & & \\
Development I-deals (6) & -0.007 & $0.156^{* *}$ & -0.144 & 0.093 & $0.746^{* *}$ & 1.000 & \\
LMX quality (7) & 0.093 & -0.105 & -0.060 & 0.067 & $0.734^{* *}$ & $0.475^{* *}$ & 1.000 \\
\hline
\end{tabular}

**. Correlation is significant at the 0.01 level (2-tailed). $\mathrm{N}=302$

Correlation analysis was conducted to test hypotheses 1, 2, and 3. Results revealed that development idiosyncratic deals and employee performance were positively and significantly related $\left(\mathrm{r}=.746^{* *}\right.$, sig.<.01), 
implying that granting employees with customized development opportunities is associated positively with Employee performance. This was in support of H1.

The findings further show a significant positive relationship between LMX quality and employee performance $(\mathrm{r}=.734 * *$, sig. $<.01)$, meaning that high levels of affect, contribution, professional respect, and loyalty between the supervisor and employee associated with a positive task and contextual performance levels. This finding supported H2.

The relationship between development idiosyncratic deals and LMX quality was found to be positive and significant $\left(\mathrm{r}=.475^{* *}\right.$, sig. <.01). Receiving of career development opportunities by employees is related to the nature of exchange relations that exist between employees and their leaders. This finding supported H3.

Table 2: Regression model results (Total effect)

Unstandardized Coefficients Standardized Coefficients $\quad$ t $\quad$ Sig.

\begin{tabular}{llllll}
\hline & B & Std. Error & Beta & & \\
(Constant) & 2.1287 & .0833 & & 25.5583 & .000 \\
Development I-deals & .4448 &. .0229 & .7462 & 19.4164 & .000
\end{tabular}

Dependent Variable: Employee Performance

$\begin{array}{ll}\mathbf{R} & .7462 \\ \mathbf{R} \text { Square } & .5569 \\ \text { Std. Error of the Estimate } & .1028 \\ \text { F Statistic } & 376.9984 \\ \text { Sig. } & .000\end{array}$

The regression results from the Hayes model in testing for mediation revealed a significant effect of development idiosyncratic deals on employee performance, with an $\mathrm{R}^{2}=.5569$. This created the ground for analysis of the mediation results.

Table 3: Mediation Analysis results

\section{Total effect of $\mathbf{X}$ on $\mathbf{Y}$}

\begin{tabular}{lccccccc}
\hline Effect & SE & $\mathbf{t}$ & $\mathbf{p}$ & LLCI & ULCI & c_ps & c_cs \\
.4448 & .0229 & 19.4164 & .000 & .3997 & .4899 & .9252 & .7462 \\
Direct effect of X on Y & & & & & & & \\
Effect & SE & $\mathbf{t}$ & $\mathbf{p}$ & LLCI & ULCI & $\mathbf{C}^{\prime} \_p s$ & $\mathbf{C}^{\prime} \_c s$ \\
.3059 & .00198 & 15.42228 & .000 & .2669 & .3450 & .6364 & .5133
\end{tabular}

Indirect effect of $\mathrm{X}$ on $\mathrm{Y}$

$\begin{array}{lll}\text { Effect BootSE BootLLCI BootULCI } & \text { B }\end{array}$

LMX 1.389

0.157

.1090

.1708

Level of confidence for all confidence intervals in the output: 95.0

Number of bootstrap samples for percentile bootstrap confidence intervals: 5000 
Mediation analysis was carried out using the Hayes Process macro model 4 to examine the mediating effect of Leader-Member-Exchange on the relationship between development idiosyncratic deals and employee performance. The result revealed a total effect of $\beta=.4448, p<.000$. The direct effect was $\beta=.3059, p<.000$, and the indirect effect were $\beta=.1389, p<.000$. The reduction in the effect size from the total effect to the direct effect and the indirect effect confirms the partial mediation effect. It reveals that LMX mediates the relationship between development idiosyncratic deals and employee performance among ICT staff.

Furthermore, to confirm the significant mediation is the Lower Limit and Upper Limits confidence intervals that do not comprise a zero. Leader-member exchange quality, therefore, enhances the relationship between granted individualized career development opportunities and the performance of the receivers of these opportunities. These results accept hypothesis $\mathrm{H}_{4}$; Leader-member exchange has a mediating effect on the relationship between idiosyncratic deals and employee performance.

\section{Discussion}

From the results, we note that customized career development opportunities granted to employees in ICT firms are positively and significantly related to their performance. This implies that these unique opportunities create space for improvement in skills and competencies on the job, creating masterly for positive employee performance (Guerrero, 2016). The ICT sector is highly technical in operations and therefore requires the matching level of skills and competencies to perform. This means that career development idiosyncratic deals are important in building these skill sets both on-the-job and off-the-job increasing their knowledge of the job and their performance. Basing on the social exchange theory, the granting of customized development opportunities for employees also creates the will to reciprocate through positive job outcomes.

Leader-member exchange is significantly and positively related to employee performance. The quality of the exchange relationship between leader and subordinate creates the environment and general mood in which tasks are performed. The high level of skill requirements for tasks in many ICT roles necessitates sound leadermember exchanges to achieve a desirable level of employee performance. Leaders and members' relationships are characterized by high levels of professional respect on the job a blooming workplace environment for employees by providing the necessary on-the-job and off-the-job support for the attainment of desirable tasks contextual performance.

Findings further indicated that Leader-member exchange mediates the relationship between development idiosyncratic deals and employee performance. Granting employees customized career development opportunities in the form of training, mentoring, and other skills enhancement programs will yield positive employee performance and be augmented by their ongoing Leader-Member exchanges with their supervisors. The requests for these negotiations of specific opportunities that meet individual interests of the employee usually are regulated by their supervisors, implying that with high-quality relationships, the effect of development idiosyncratic deals on employee performance is likely to be enhanced. Rousseau (2015) explains that career development-related idiosyncratic deals created opportunities for skill improvement and career progression. In instances especially of on-the-job training opportunities, the roles of the quality of exchanges between the employees and leader cannot be ignored, as confirmed in this study. Contextually, this is justified by the nature of the work of ICT staff, which is primarily technical, requiring continuous skills enhancement warrantying the relevance of the roles of supervisors to guide the performance of employees.

\section{Conclusion}

Development idiosyncratic deals are relevant in the contemporary world for staff of ICT companies given the continuous improvement in technology that requires constant improvement in the employees' skill sets to achieve the desired performance levels. Also, the quality of the Leader-member exchanges is vital for the 
attainment of positive employee job performance. With the granting of development idiosyncratic deals, leadermember exchanges enhance the relationship with employee performance.

ICT organizations are technology-driven firms which should adopt and incorporate development idiosyncratic deals as contemporary workplace practices to drive positive job performance. Given the potential of these idiosyncratic deals to improve the employees' skill set for a particular job, ICT firms should put in place avenues to advance their employees' unique career development needs. Personalized workplace development opportunities have proven to create a reciprocity obligation on the employee as supported by the social exchange theory. This stance has further been demonstrated as relevant following the outbreak of the Covid19 pandemic that called for practices such as social distancing and advocating for working in varied places other than the official designated company premise to reduce the spread of the virus. This situation warrants that employees have the necessary expertise and skills to perform remotely, and these can be attained through granting these unique development opportunities. Also, given the constant advancement of technology, ICT firms being at the forefront of the provision of ICT services ought to be up to date with the latest trend, which permits the provision of development idiosyncratic deals to drive employee performance.

\section{Implications of the study}

This study has valuable implications for theory and practice. The findings confirm the reciprocal foundation upon which the social exchange theory is built. According to the social exchange, theory employees have exchange relationships that yield mutual benefits and costs (Cropanzano, Anthony, Daniels, \& Hall, 2017). In this case, the employee feels obliged to reciprocate a favor granted by the employer regarding an opportunity to develop their career by ensuring improved job outcomes, which is in the employer's interest. Therefore, consistent with the study findings, the granting of idiosyncratic deals to employees will motivate them to respond with improved employee performance. The study basing on the significant relationship between development-related idiosyncratic deals and employee performance affirms the nature of the social exchange relationship present among employees of ICT companies in Uganda.

In the ICT context, development idiosyncratic deals have a workable space given that the study has proven that they have a positive relationship with employee performance. Therefore, managers and leaders of staff in ICT companies ought to encourage employees to seek these customizations of on and off-the-job development opportunities that match their interests. These arrangements in the workplace help to build the will of reciprocation with improved job outcomes from employees, given that these conditions of employment address their unique or unmet individual development needs. Managers and other leaders in different units of the ICT organization should ensure that effective negotiations are granted. Emphasis should also be on building the quality of exchange relationships between leaders and subordinates to ensure that power distances are shortened to improve loyalty, professional respect, and contribution with their subordinates to enhance the performance.

\section{Limitations and areas of further research}

Even with key contributions to the literature on idiosyncratic deals and employee performance, this study does not go without limitations. The study was cross-sectional and this could have affected the nature of responses gathered in the survey. Future researchers should compare with longitudinal studies to assess the development idiosyncratic deals and employee performance over time. The study was also purely quantitative, which could have limited the ability to understand idiosyncratic negotiations in an untapped context like Uganda. We call upon researchers to employ qualitative or a mixed-methods approach in similar contexts.

Also, this study concentrated on the ex-post idiosyncratic deals of employee development, and future studies could explore the ex-ante Idiosyncratic deals to assess their influence on future job outcomes. 
The opportunity for future research is to focus on the customization of workplace practices and systems to match the demands of the new era brought about by the Covid-19 Pandemic and its effects on the workplace. This can be examined in terms of customized schedules, rewards, and employment as the future of employment takes a new dynamic.

Funding: This research received no external funding.

Acknowledgments: We acknowledge Moi University, Kenya for the provision of access to online journal materials used in this study.

Conflicts of Interest: The authors declare no conflict of interest.

\section{References}

Anand, S., Hu, J., Vidyarthi, P., \& Liden, R. C. (2018). Leader-member exchange as a linking pin in the idiosyncratic deals-Performance relationship in workgroups. The leadership quarterly, 29(6), 698-708.

Attia, E.-A., Duquenne, P., \& Le-Lann, J.-M. (2014). Considering skills evolutions in multi-skilled workforce allocation with flexible working hours. International Journal of Production Research, 52(15), 4548-4573.

Bal, P. M., \& Boehm, S. A. (2019). How do I-deals influence client satisfaction? The role of exhaustion, collective commitment, and age diversity. Journal of Management, 45(4), 1461-1487.

Blau, P. M. (1964). Social exchange theory. Retrieved September, 3(2007), 62.

Blau, P. M. (1968). Social exchange. International encyclopedia of the social sciences, 7, 452-457.

Bos-Nehles, A. C., \& Meijerink, J. G. (2018). HRM implementation by multiple HRM actors: A social exchange perspective. The International Journal of Human Resource Management, 29(22), 3068-3092.

Carter, M. Z., Armenakis, A. A., Feild, H. S., \& Mossholder, K. W. (2013). Transformational leadership, relationship quality, and employee performance during continuous incremental organizational change. Journal of organizational behavior, 34(7), 942-958.

Cropanzano, R., Anthony, E. L., Daniels, S. R., \& Hall, A. V. (2017). Social exchange theory: A critical review with theoretical remedies. Academy of Management Annals, 11(1), 479-516.

Epitropaki, O., \& Martin, R. (2005). From ideal to real: a longitudinal study of the role of implicit leadership theories on leader-member exchanges and employee outcomes. Journal of Applied Psychology, 90(4), 659.

Graen, G. B., \& Uhl-Bien, M. (1995). Relationship-based approach to leadership: Development of leadermember exchange (LMX) theory of leadership over 25 years: Applying a multi-level multi-domain perspective. The leadership quarterly, 6(2), 219-247.

Guerrero, S., Jeanblanc, H., \& Veilleux, M. (2016). Development idiosyncratic deals and career success. Career development international.

Hornung, S., Rousseau, D. M., \& Glaser, J. (2008). Creating flexible work arrangements through idiosyncratic deals. Journal of Applied Psychology, 93(3), 655.

Hornung, S., Rousseau, D. M., \& Glaser, J. (2009). Why supervisors make idiosyncratic deals: Antecedents and outcomes of I-deals from a managerial perspective. Journal of Managerial Psychology, 24(8), 738-764.

Hornung, S., Rousseau, D. M., Weigl, M., Mueller, A., \& Glaser, J. (2014). Redesigning work through idiosyncratic deals. European Journal of Work and Organizational Psychology, 23(4), 608-626.

Kim, M.-S., \& Koo, D.-W. (2017). Linking LMX, engagement, innovative behavior, and job performance in hotel employees. International Journal of Contemporary Hospitality Management.

Leroy, H., Segers, J., Van Dierendonck, D., \& Den Hartog, D. (2018). Managing people in organizations: Integrating the study of HRM and leadership: Elsevier.

Li, X., Sanders, K., \& Frenkel, S. (2012). How leader-member exchange, work engagement and HRM consistency explain Chinese luxury hotel employees' job performance. International Journal of Hospitality Management, 31(4), 1059-1066. 
Liao, C., Wayne, S. J., Liden, R. C., \& Meuser, J. D. (2017). Idiosyncratic deals and individual effectiveness: The moderating role of leader-member exchange differentiation. The leadership quarterly, 28(3), 438-450.

Liao, C., Wayne, S. J., \& Rousseau, D. M. (2016). Idiosyncratic deals in contemporary organizations: A qualitative and meta-analytical review. Journal of organizational behavior, 37, S9-S29.

Liden, R. C., \& Maslyn, J. M. (1998). Multidimensionality of leader-member exchange: An empirical assessment through scale development. Journal of Management, 24(1), 43-72.

Martin, R., Guillaume, Y., Thomas, G., Lee, A., \& Epitropaki, O. (2016). Leader-member exchange (LMX) and performance: A meta-analytic review. Personnel Psychology, 69(1), 67-121.

Martin, R., Thomas, G., Charles, K., Epitropaki, O., \& McNamara, R. (2005). The role of leader-member exchanges in mediating the relationship between locus of control and work reactions. Journal of Occupational and Organizational Psychology, 78(1), 141-147.

Muchinsky, P. M. (2006). Psychology applied to work: An introduction to industrial and organizational psychology: Cengage Learning.

Rosen, C. C., Slater, D. J., Chang, C.-H., \& Johnson, R. E. (2013). Let's make a deal: Development and validation of the ex post i-deals scale. Journal of Management, 39(3), 709-742.

Rousseau, D. (2015). I-deals: Idiosyncratic Deals Employees Bargain for Themselves: Idiosyncratic Deals Employees Bargain for Themselves: Routledge.

Rousseau, D. M., Hornung, S., \& Kim, T. G. (2009). Idiosyncratic deals: Testing propositions on timing, content, and the employment relationship. Joumal of Vocational Behavior, 74(3), 338-348.

Rousseau, D. M., \& Kim, T. (2004). Idiosyncratic deals: How negotiating their own employment conditions affects workers' relationships with an employer. Unpublished manuscript, Carnegie Mellon University, Pittsburgh, $P A$.

Rousseau, D. M., Tomprou, M., \& Simosi, M. (2016). Negotiating flexible and fair idiosyncratic deals (i-deals). Organizational dynamics, 45(3), 185-196.

Shore, L. M., Coyle-Shapiro, J. A., Chen, X.-P., \& Tetrick, L. E. (2009). Social exchange in work settings: Content, process, and mixed models. Management and Organization Review, 5(3), 289-302.

Sihombing, S., Astuti, E. S., Al Musadieq, M., Hamied, D., \& Rahardjo, K. (2018). The effect of servant leadership on rewards, organizational culture and its implication for employee's performance. International Journal of Law and Management.

Srikanth, P. B., Jomon, M., \& Thakur, M. (2020). Developmental idiosyncratic i-deals and its influence on promotability decisions: the joint roles of proactive personality and developmental challenge. The International Journal of Human Resource Management, 1-26.

Sun, N., Song, H., Kong, H., \& Bu, N. (2020). Development and validation of a hospitality idiosyncratic deals scale. International Journal of Hospitality Management, 91, 102416.

Townsend, J., Phillips, J. S., \& Elkins, T. J. (2000). Employee retaliation: The neglected consequence of poor leader-member exchange relations. Journal of Occupational Health Psychology, 5(4), 457.

Volini, E., Schwartz, J., Roy, I., Hauptmann, M., Van Durme, Y., Denny, B., \& Bersin, J. (2019). Leading the Social Enterprise: Reinvent with a Human Focus.

Williams, L. J., \& Anderson, S. E. (1991). Job satisfaction and organizational commitment as predictors of organizational citizenship and in-role behaviors. Journal of Management, 17(3), 601-617. 